\title{
Application of the Industry-based Theory the Case of Mexican Company CEMEX
}

\author{
Vargas Hernández JG* and Martin De La Rosa Plascencia
}

University Center for Economic and Administrative Sciences, University of Guadalajara, México

\begin{abstract}
The way in which an industry is organized is an important aspect to be taken into account when you plan to make the study of a particular company. The structure of the industry influences the results of the companies that comprise it. The analysis must consider differences among sectors, features that also share companies; therefore the impact of each industry can be reflected in different ways in the firms. In this sense this paper studies the behavior of the company Cementos Mexicanos CEMEX. For this, an overview of the performance of the construction is presented, to which the company belongs. Finally, CEMEX is analyzed using Porter's diamond.
\end{abstract}

Keywords: Generic strategies; Industry structure; Porter's diamond

\section{Introduction}

The analysis of the environment in which different companies are interacting with them, can identify a range of opportunities and threats that influence the conduct to be adopted by each of the firms. However, for companies to have a better view of the elements that impact performance, should also conduct a study inward on them that will identify the internal factors from which it is possible to build a competitive advantage [1]. In this sense, the companies, through recognition of certain internal and external elements define a strategy to ensure their survival in the complex and changing characteristics of the environment in which they operate.

Based on the above, emerges the structure- behavior (strategy) result (yield) pattern, which basically means that the yield obtained by a company depends on the features that have the industry in it which is competing (Porter Based on the above, the structure pattern emerges,) [2]. In this context, the industry structure determines the behavior (strategies) of firms in the market Bain, and in turn, strategies define yields [3]. However, Porter states that to explain the existence of differences in returns of enterprises, it is possible to ignore the behavior and look directly into the structure of the sector, which according to the author it is valid because it is a simple reflection of the environment [2].

Market structure refers to certain attributes of a relatively stable industry that provide the context in which competition takes place $[4,5]$. The elements of such a structure that influence business performance include the number and size of firms, product differentiation, barriers to entry and the elasticity of demand [3]. The strategy arises from the need to guide decisions according to the position that companies have on the environment [2], and it is defined as the direction given to the resources of a firm to modify, adapt or possibly survive the conditions of the economic environment [6]. Finally, Porter indicates that the performance encompasses profitability, minimization of costs and innovation [2].

At this point, it is possible to indicate that the market structure, in which a company participates, shapes the results to be gotten in the future, and therefore, it is necessary that senior managers make strategic decisions that will enable the firm to obtain the expected performance. In this context, Porter identifies a specific type of strategy, which called competitive strategy [1]. This author indicates that the competitive strategy comes from the premise that the factors that shape the behavior of each industry influence companies.
Something that has not been mentioned in this paper is that there is the possibility that this causation flows in the opposite direction, which occurs when the results of the companies within an industry, shaping the structure of the market, despite of that. Therefore, this case is not dealt with in this paper. However, does not imply that is minimizing the importance of this focus.

From the above discussion, it appears that in 1980, Porter has a tool to analyze the structure of an industry from what he called the five competitive forces [1]. These forces are going to be the focus of this paper. However, despite the great contribution made by the author's analysis of industrial competition, its approach is incomplete, first, because it is based on a static analysis, which prevents to observe what happens in the industry with the existence of rapid changes in the environment. Second, because this model only allows analyzing the industry in general [6].Therefore, it is necessary to include in the analysis the theory based on resources and capabilities as well as the institutional theory. However, the current study dispenses to include such approaches.

\section{The Tripod Strategy}

As mentioned in the introduction, for companies to achieve to design a competitive strategy, it is necessary to identify some relevant factors that affect their behavior and performance. In this sense, it appears the so-called tripod of the strategy, which consists of the theory based on the viewpoint of the industry. A second front is the resources and capabilities own by the firm, same which in turn allow responding in various ways to the conditions of the economic environment. And finally, the analysis would not be complete without evaluation of the impact of institutions, culture and ethics in the behavior of individuals and businesses. However, in this first attempt, it only includes the development of vision based on the theory of industry.

*Corresponding author: Vargas Hernández JG, University Center for Economic and Administrative Sciences, University of Guadalajara, México; Tel:+5233-37703340; E-mail: jvargas2006@gmail.com

Received June 26, 2015; Accepted August 11, 2015; Published August 18, 2015

Citation: Vargas Hernández JG, Plascencia MDLR (2015) Application of the Industry-based Theory the Case of Mexican Company CEMEX J Glob Econ 3: 152. doi: $10.4172 / 2375-4389.1000152$

Copyright: (c) 2015 Vargas Hernández JG, et al. This is an open-access article distributed under the terms of the Creative Commons Attribution License, which permits unrestricted use, distribution, and reproduction in any medium, provided the original author and source are credited. 


\section{The theory based on industry}

Porter defines as a sector or industry, the group of companies that produce goods that are close substitutes for each other [1]. Moreover, Peng provides a similar definition. For this author the industry is a group of companies or firms producing identical goods and services [7]. The vision of the strategy based on the industry is supported by the five forces framework developed by Porter [1]. These five forces are: The intensity of the rivalry between the competitors, the threat of potential entry, power trading of both suppliers and buyers and the possibility of appearing substitute products, which are developed below.

The intensity of rivalry among competitors: Porter identifies some elements that considered influence the degree of rivalry among competitors [1]. The author mentions the following: price competition, advertising battles, the proliferation of new products, and finally, action of competition and reaction of low cost. These actions tend to diminish the profits of the firms, which occurs because, as he argues, companies are mutually dependent.

Another important implication to which reference is made is that the intensity of the rivalry is the result of the interaction of a set of structural factors, including among others, the author identifies the following: The number of competitors of similar size, slow growth and decay industry, high fixed or storage costs, increase production capacity in large quantities, the existence of high exit barriers, etc.

The threat of potential entry: How is distributed the industry impacts the results of the companies that compose it. In this sense, the emergence of new competitors means that for established firms see their profits diminished. As a result of this, the owners seek to limit the entry of new companies, increasing the barriers to entry Porter [1]. Among which, the author identifies the following: advantages based on economies of scale, product differentiation, capital requirements, the disadvantage of costs that are independent of scale, access to distribution channels and government policy. Finally, for Peng holders are members who currently belong to the industry and are competing with each other [7]

The bargaining power of suppliers: Porter indicates that the bargaining power of suppliers refers to the ability that they have to raise prices or reduce the quality of goods and services that the customer requires in the production chain [1]. Peng indicates that suppliers are organizations that provide such things as materials, services and labor in an industry [7]. Finally, both Porter and Peng indicate that the existence of few companies that dominate the industry and have the ability to offer these unique and different with few or no substitute products, is an important element to them to acquire a high bargaining power $[1,7]$.

The bargaining power of buyers: Porter mentions that a buyer group is powerful if the following conditions are valid: it is concentrated or purchases large volumes relative to seller sales [1]. Purchase products of the industry that represent a significant fraction of the costs or the buyer purchases, purchase products of the industry that are standard or undifferentiated, and the buyer has complete information, among others. Peng indicates that a small number of buyers lead to a strong bargaining power, because it puts competing suppliers, which can get better prices and quality [7].

The threat of substitutes: Porter mentions that the markets or segments where there are substitute products are not attractive for investment because of the latent risk that the profit margins of the firm or industry may be reduced [1]. In that sense, companies that are already established in a market use entry barriers as a strategy to cope with the possible emergence of substitutes. However, replacers can occur due to two specific situations. One is that the replacers are superior in quality and function to existing products, and two, if switching costs are low.

\section{The theory based on resources and capabilities}

In this section the framework of resources and capabilities is presented. This approach suggests that differences in the performance of companies are caused by differences in resources and capabilities that the company has. Peng defined as the tangible resources and intangible assets used by a firm to choose to support their strategies [7]. While the author indicates that the capabilities are the tangible and intangible assets used by firms to choose and implement their strategies. Peng indicates that the resource-based view focuses on aspects of value $(\mathrm{V})$, rarity $(\mathrm{R})$, imitation $(\mathrm{I})$ and organization $(\mathrm{O})$ [7].

\section{Institutions}

The institutions are defined by North [8] as the rules of the game governing the behavior of a society. He argues that the main purpose of institutions is to reduce uncertainty. In that sense, it becomes a guide that enables good performance in human and business interactions. On the other hand, the author classifies institutions as formal and informal. Formal institutions are defined as the rules that individuals create and informal institutions as the conventions and codes of conduct. In this regard, Peng argues that in addition to the conditions at the level of the firm and industry, policy makers must take into account the influence of the state and society [7].

\section{The Generic Strategies}

Once the five competitive forces have been identified affecting the competitiveness of the company, it is necessary that senior management makes strategic decisions that will enable the firm to have higher yields and better performance. In this regard, Peng states that when a company decides to enter any industry, an option that should be considered is to enter industries where the five forces are weaker, which will aloe to consolidate a strong position and defensible [7] Porter provides a framework for making strategic decisions which are known as generic strategies as they are described below [1].

\section{The strategy based on cost leadership}

Porter states that to achieve cost leadership, it is necessary to have a set of functional policies directed towards this goal [1]. Therefore, this author argues that the leadership in costs requires building efficient scale facilities, constant quest to reduce costs associated with the experience, control overhead and minimizing costs in several areas. However, Peng shows that this strategy is based on offering a product that has the same value as others on the market but at a lower price [7]. This author identifies two disadvantages. Firstly, the possibility of being exceeded in costs, resulting continuous reductions, and on the other, that the relentless fight to reduce costs have negative impacts on consumer welfare.

\section{The strategy based on differentiation}

According to Porter, differentiation can take various dimensions ranging from brand image, technology, and customer service and distribution network among others [1]. This strategy is based on providing consumers with products that are valuable to them and different, and from this, ensure that consumers are willing to pay a higher purchase price. Peng indicates that this approach has two disadvantages. First long-term product differentiation cannot be 
maintained, and on the other, one must be careful that rival firms fail to mimic products [7].

\section{The strategy based on the approach}

This strategy focuses on covering a specific industry segment, which can be according to the product line or in a geographical area. Porter argues that the strategy of approach can take many forms [1]. Further he suggests that different from the other two strategies is that the focus is only on a particular target, this occurs because it is assumed that the company is able to serve more efficiently to its strategic objective manner when attending one point that when trying to address the generality.

\section{The construction Industry in Mexico}

For this section it must be remembered that several authors have mentioned in theory, that the behavior of the industry where a company is located, shapes the behavior and performance of the same. In this sense, this section analyzes how the construction industry behaves in Mexico, for which data on the total gross production INEGI were obtained and proceeded to develop the concentration index of Herfindahl - Hirshman (HHI) at national level [9]. Results were obtained in a value equal to 0.13 for the $\mathrm{HHI}$, indicating that the structure of the industry tends to be oligopolistic.

Table 1 show that the total gross output of the construction industry nationwide is concentrated in firms with more than thirty employees, except for companies employing five hundred to a thousand and one workers. To make this selection the average participation by stratum is $0.08(8 \%)$ and was chosen levels that showed a higher participation than the average. Something that is important to note is that the participation of the five selected categories explained $74 \%$ of the total gross output of the industry.

According to the theory, one of the elements that have an important character when it seeks to explain the behavior of a firm within an industry is the number of competitors participating in it. In the case of Mexico's construction sector, Table 2 shows that the concentration of competitors is in companies that have fewer than 50 employees, whose participation adds $85 \%$. Again the approach that was taken into account was to select the layers that are above average.

On the other hand, something that is important to point out is that there is a difference between the number of economic units reported by the 2009 Economic Census, in contrast to the one provided by the National Statistics Directory of Economic Units, which it is also issued by the National Institute of Statistics and Geographical $[9,10]$. Another difference that arises is the number of strata used for classifying the size of the economic units. The information obtained had to be organized from dynamic tables for totals by strata.

Table 1 is shown below, from it which can be said that 2014 had recorded 20.330 economic units related to the construction industry in Mexico, and that of all of these units, 7,938 (39.05\%) were between 0 to 5 employees, while 3,090 (15.20\%) had between 6 and 10 employees, and there are 5,378 (26.45\%) firms that have between 11 and 30 workers, and identified 1,528 (7.52\%) companies that have between 31 and 50 workers (Figure 1).

On the other hand, it is known that 1,198 (5.89\%) recorded between 51-100 employees while 737 (3.63\%) are between 101 and 250 people working. Finally there are $461(2.27 \%)$ companies employing 251 people or more. Nationally, the concentration of economic units are located in companies employing fewer than thirty people, which represents $(85 \%)$ of the existing economic units.
An important consideration is that not all states are facing the same economic conditions. Therefore, it was considered important to develop (Figure 2), with the intention of observing the states which have the largest number of economic units in the Mexican republic. For practical reasons, there have been considered taking into account only the states with more than 1,000 economic units, without downplay the involvement of others. In this sense, it can be seen that the Federal District (key E.9) has 1,839 firms. The second state is Nuevo Leon (Key E.19) with 1,307. The third is Jalisco (key E.14) with 1,300. Finally, the state of Guanajuato (Key E.11) has 1,022 signatures (Figure 2).

From the above it is possible to advance one of the conclusions of the analysis that should emerge later and will be in relation to the company Cementos Mexicanos [11]. This lies in stating that CEMEX has taken as strategic centers to Mexico City, Nuevo Leon and Jalisco for the production and distribution of its products, which has been a foundation for expansion. In this sense, then analyzing the industry for only three states that are of interest, takes place, stating that these are important centers of location, and companies that can position in these markets have an advantage over others [10].

\section{The construction industry in the Federal District}

In the case of the Federal District, the construction Grupo Cementos de Chihuahua industry is concentrated mainly in companies

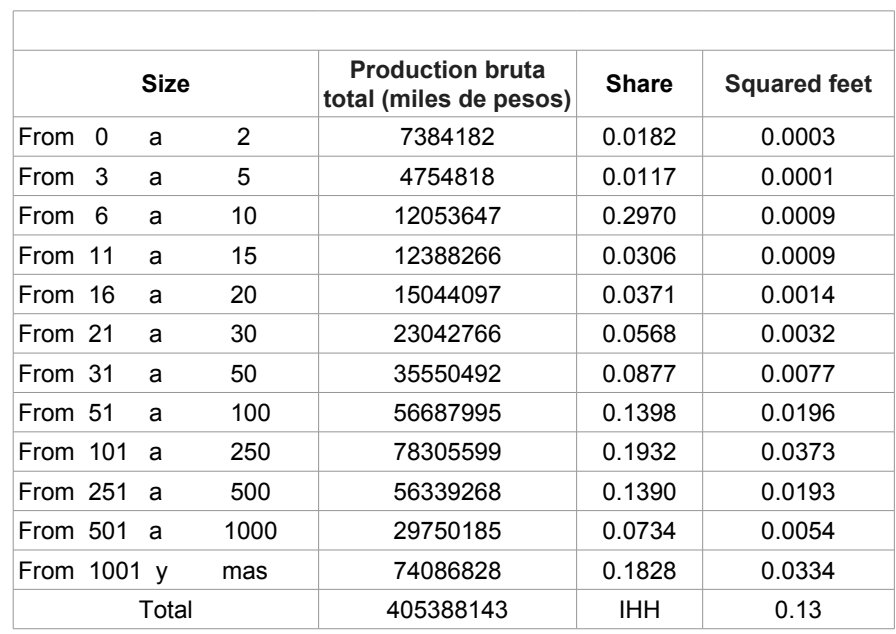

Source: INEGI [9].

Table 1: National data to calculate the Herfindahl-Hirshman Index (HHI).

\begin{tabular}{|c|c|c|c|}
\hline \multicolumn{2}{|r|}{ Size } & National & Share \\
\hline From 0 & 2 & 2471 & 0.1326 \\
\hline From 3 & 5 & 2400 & 0.1288 \\
\hline From 6 & 10 & 3041 & 0.1632 \\
\hline From 11 & 15 & 2340 & 0.1256 \\
\hline From 16 & 20 & 1701 & 0.0913 \\
\hline From $21 \quad a$ & 30 & 2023 & 0.1085 \\
\hline From 31 & 50 & 1942 & 0.1042 \\
\hline From 51 & 100 & 1479 & 0.0794 \\
\hline From 101 a & 250 & 834 & 0.0447 \\
\hline From 251 a & 500 & 273 & 0.0146 \\
\hline From 501 a & 1000 & 89 & 0.0048 \\
\hline From $1001 \mathrm{y}$ & mas & 44 & 0.0024 \\
\hline \multicolumn{2}{|c|}{ Total } & 18637 & 1 \\
\hline
\end{tabular}

Source: INEGI [9].

Table 2:Number of economic units in construction industry (National). 


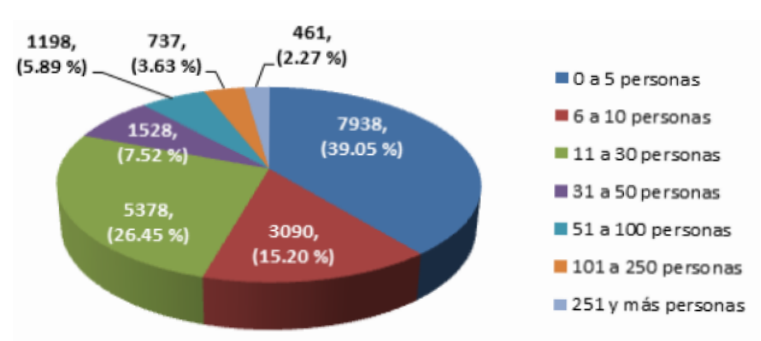

Figure 1: Records of 2014 economic units related to the construction industry in Mexico.

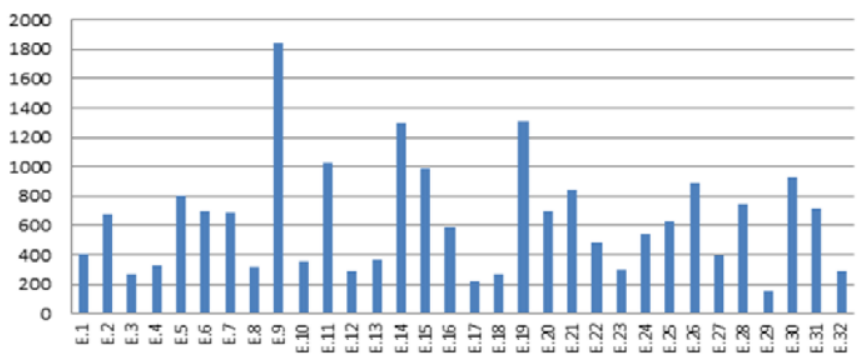

Source: INEGI $[9,10]$

Figure 2: Composition of Economic Units by States.

employing fewer than thirty people, so that only businesses with five or fewer employees account for $50 \%$ of the sector [12]. While on the other hand, it appears that firms employing thirty employees or less account for $79 \%$ of existing economic units. This tells that there is a high concentration of micro and small companies. The section consists of 1,839 economic units in the region and visual description can be obtained by reviewing (Figure 3 ).

A further description of Figure 3, suggests that by 2014, from the total 1,839 of economic units related to the construction industry in the Federal District, 910 (49.48\%) employed between 0 and 5 employees, while 220 (11.96\%) had between 6 and 10 employees. Besides, there are $320(17.40 \%)$ firms that indicated to have between 11 and 30 workers, and were identified $130(7.07 \%)$ companies that had between 31 and 50 workers. Also, it is known that $99(5.38 \%)$ employed 51 to 100 employees while $81(4.40 \%)$ were between 101 and 250 people working. Finally, there are $79(4.30 \%)$ companies employing 251 people or more.

\section{The construction industry in Nuevo León}

Another center of economic development of the country is undoubtedly Nuevo Leon. In this sense, the Economic Census analyzes how the construction industry in this state behaves. To provide a visual support was drawn Figure 4.

The results indicate that the construction industry behaves in a similar manner as in the case of the Federal District. In the case of Nuevo Leon, it shows that the highest concentration is in companies with thirty or fewer employees, who represents $81 \%$ of economic units registered in the region. This industry comprises 1,307 registered economic units in the DENUE [10].

In the case of Figure 4, it can be said that of the total (1307) of economic units related to the construction industry in Nuevo Leon, 512 (39.17\%) economic units have 0 to 5 employees, while $190(15.54 \%)$ have between 6 and 10 employees. Besides, there are 352 (26.93\%) firms that have between 11 and 30 workers, and were identified 87 (6.66\%) companies with between 31 and 50 workers. Furthermore, it is known that $93(7.12 \%)$ have 51 to 100 employees, while $43(3.29 \%)$ are between 101 and 250 people working. Finally there are $30(2.30 \%)$ companies employing 251 people or more.

\section{The construction industry in Jalisco}

Now, it's time to study the behavior of the construction industry in Jalisco. The results indicate that the same pattern as in the two cases presented above, the Federal District and Nuevo Leon presents this same pattern. This pattern is that the concentration of economic units is located in companies with fewer than 30 employees, which together explain $83 \%$ of the total. The construction industry in Jalisco is comprised of a total of 1,300 companies registered in the National Statistics Directory of Economic Units provided by the INEGI [9]. From the data obtained the following chart was developed [10].

In Figure 5, it can be seen that there are a total of 1,300 economic units related to the construction industry in the state, of which 450 (34.62\%) had between 0 and 5 employees in Jalisco, while $222(17.08 \%)$ they had 6-10 people working. Besides, there are 315 (24.23\%) firms dealing with 11-30 workers and also have identified 99 (7.62\%) companies with between 31 and 50 employees. On the other hand, it is known that 105 (8.08\%) had 51-100 employees, while 60 (4.62\%) had between 101 and 250 working people. Finally, 49 (3.77\%) companies were employing 251 people or more.

\section{History of CEMEX}

CEMENTOS MEXICANOS (CEMEX) The company was founded in 1906 and over the years has positioned both domestically, and internationally. This company is dedicated to the production of cement, concrete and construction-related products. An important observation is that in 1985 CEMEX production exceeded one million tons per year only with the operation of three of its plants, namely the plant Monterrey, Guadalajara and Torreon ground floors which is consistent with the results obtained in the previous section. From industry analysis, it was possible to observe that three places, Mexico City, Nuevo Leon and Guadalajara concentrate the greater number of economic units [11].

\section{Implementation of the Five Forces Framework of the Company "CEMEX"}

As described in this study, it is important that companies assess the impact that the economic environment may have on their future performance, which should be complemented by the development of an internal analysis. This complementarity will allow firms to identify on one hand the threats and opportunities prevailing in the environment as well as the strengths and weaknesses that will allow coping or succumbing to complex situations. Thus, from the conjunction of both external factors and internal, companies can identify opportunities and mitigate risks, becoming more competitive in their daily action. Thus, in this section shall be carried out applying the five forces framework to the case of CEMEX [11].

\section{Intensity of rivalry from competitors}

The market for cement, concrete and its derivatives in Mexico is made up of at least six participating firms. Among them, it is possible to identify three of them competing globally, for example CEMEX, Holcim-Apasco and Lafarge. However, in the case of Mexico, it appears that is CEMEX who leads the shares in that market. In this regard, the company has fifteen plants distributed throughout the national territory 


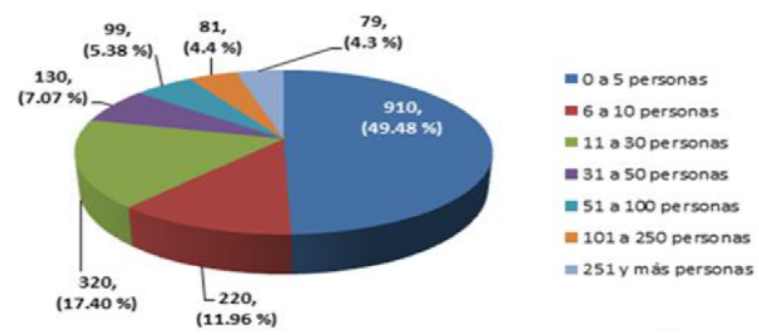

Figure 3: Economic units in the construction industry of the Federal District; Percentages by strata of employed people.

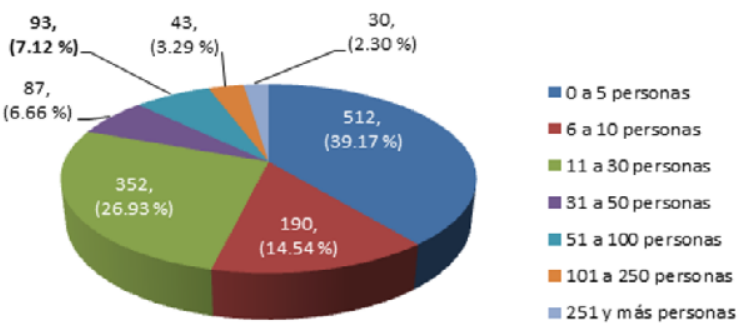

Source: INEGI $[9,10]$

Figure 4: Economic units in the construction industry of Nuevo León. Percentage per strata of employed people.

[13]. Besides, it produces nearly $50 \%$ of all cement is distributed in the domestic market (Table 3) [14].

Among the closest rivals of CEMEX it is possible to identify HolcimApasco who has seven production facilities in Mexico, and is capable of producing $18.89 \%$ of the country's cement demand[13,14]. On the other hand, the Cooperativa Cruz Azul (Cooperative Blue Cross) has four floors and is capable of producing $18.29 \%$. Grupo Cementos de Chihuahua has three plants and brings to market the $12.89 \%$ (Americas Business Insight in Latin America, 2015); while Cementos Moctezuma also has three plants, however, only it has the capacity to produce $2.7 \%$ $[13,15]$.

Finally, the case of Cementos Fortaleza, which has a production capacity of $3.3 \%$ and has only two floors $[13,16]$. The installed production capacity of cement in Mexico is 60.6 million tons (High Level, 2013). A clearer vision described, can be seen in Table 3 and Figure 6.

Americas business Insight in latin America. Date of consultation May, 2015 for the case of GCC. Holcim-Apasco [14] Date of consultation CNN Expansion for the case of Cementos Fortaleza, Cementos Moctezuma. Date of consultation. High Level (2015) installed capacity of production of cement in Mexico.

It seems that CEMEX has no potential rivals in the market for cement, concrete and its derivatives in Mexico. However, it but must pay special attention to two specific firms. First, the case of HolcimApasco, a company that through intense advertising campaigns tries to have a greater influence in this market. Second, the case of the Cooperative Blue Cross company, with three production plants less than Holcim-Apasco, it has the ability to produce a similar amount to the Swiss company [14].

\section{The threat of potential entry}

The threat of new competitor's entries to the market of cement, concrete and its derivatives in Mexico is very low, because within the industry it involves three of the most important companies worldwide. This generates in the first place, the impossibility to compete against low costs that these firms obtain by producing scale. Another important aspect is that marks and brands of these firms placed on the market already have some recognition, something that would have to get a firm to begin operations. Therefore, these companies have both the facility and the ability to generate high barriers to entry for those seeking to enter the market.

This can be easily sustained just by looking at the history of CEMEX, where it went from the use of furnaces of one step and dry process to ovens preheated of two-stage process, and from these to the furnaces with pre-heater and four stages of electrostatic precipitator. Importantly to remark that the pre-heaters of four stages of furnaces reduced installation costs so that once CEMEX benefited from the reduction of such costs. Finally, following the use of pre-heating furnaces with four stages and pre-calciner CEMEX experienced a major technological advance again that allowed decreasing installation costs as well as the related with expenditure of parts [11].

\section{The bargaining power of suppliers}

For this paper it has been seen that some suppliers of CEMEX have a high bargaining power. In this tier are those that provide inputs related to the production of cement, concrete and derivatives. Here are also located the same companies that provide service maintenance and repair the machines used in the production process, among others. These suppliers are empowered by CEMEX that is critical for their production processes to behave properly, if the company fails to get the inputs to maintain production or its furnaces were damaged, it would face a situation of declining profits. On the other hand, suppliers that do not have high bargaining power are those that provide goods and services not directly related to the production process of this company.

\section{The bargaining power of buyers}

Based on information obtained in Section III in which the construction industry in Mexico is analyzed, it can be said that 2014 had record of 20.330 economic units related to the construction industry in Mexico. One of the results obtained in section III was that the concentration of economic units is in companies with fewer than 30 employees, where $83 \%$ of the total industry is concentrated. Therefore, it has been considered within this set of economic units are the customers of CEMEX and hypothetically states that are close to 8,945 . It is said hypothetically because that amount is obtained by multiplying the total units by the percentage of market share that has CEMEX. Following this, one can say the bargaining power of buyers is low. However, there remains the question to know what stratum customers are located, which in turn would identify if the bargaining power that is different depending the size of the firm.

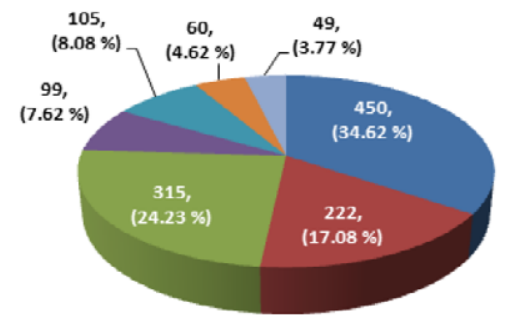

$$
\begin{aligned}
& =0 \text { a } 5 \text { personas } \\
& =6 \text { a } 10 \text { personas } \\
& =11 \text { a } 30 \text { personas } \\
& =31 \text { a } 50 \text { personas } \\
& =51 \text { a } 100 \text { personas } \\
& =101 \text { a } 250 \text { personas } \\
& =251 \text { y más personas }
\end{aligned}
$$

Source: INEGI $[9,10]$

Figure 5: Economic units in construction industry of Jalisco: Percentages by strata of employed personnel. 


\begin{tabular}{|c|c|}
\hline Business & N.De plantas \\
\hline CEMEX [11] & 15 \\
\hline Cooperative cruzazul & 4 \\
\hline Grupo cementos Chihuahua (GCC) [12] & 3 \\
\hline Holcim-apasco [14] & 7 \\
\hline Cementos strength & 2 \\
\hline Cementos moctezuma [15] & 3 \\
\hline
\end{tabular}

Source: CANACEM [13].

Table 3: Number of floor grounds by company.

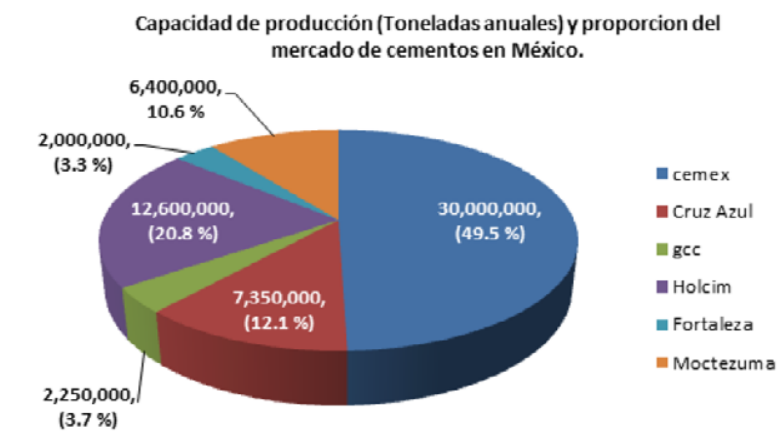

Source: Own elaboration with data from El Financiero (2014) for the case of CEMEX [11].

Figure 6: Production capacity (Annual tons.) and proportion of the markets of cements in México.

\section{The threat of substitutes}

Excelsior indicates that a group of Mexican businessmen has developed a construction product which it has been called MasaRoca, as cited in the article. This product exceeds the characteristics of traditional concrete, because it retains the adhesive qualities and coagulants which have traditional concrete. Among the benefits listed for that product it is to be pliable which allows it to be used in difficult areas to work without the need for centering. In addition, it does not require waterproofing harden because its porosity permits the passage of gas but not the water [17].

Furthermore, LR La Republica mentions that the company Cementos Argos, is developing what it is called the green cement, which is a substitute for traditional cement and is made from fly ash from coal-fired thermal plants [18]. Based on these references it is important to note that despite the existence of some traditional cement substitute products, they do not currently represent a significant threat in the use of this product. However, it is necessary that CEMEX note some considerations that allow it to respond appropriately to the appearance of potential replacements in the future.

\section{Application of the Case of CEMEX Generic Strategies}

\section{The cost leadership strategy}

In reviewing the history of CEMEX, it is possible to identify that the company has used the strategy of cost leadership during various stages of its life. This comes to light by observing how the company has been concerned throughout time to expand their product lines both in installed plants, accompanied by the production of furnaces with more production capacity, which also have better technology, which in turn allows reducing installation, maintenance and repair costs, as by geographic area, placing new plants at strategic points that allow it to cover markets located nearby, thus reducing distribution costs.

\section{The strategy of differentiation}

As for the differentiation strategy, CEMEX has several brands, distributed throughout the national territory. In addition to that in 2001, the company launches, Construrama which is a chain of stores located in Mexico, which is dedicated to supplying and providing building materials. On the other hand, in this same year, the company made an important twist step in implementing their sales strategies, because started serving their customers online. Finally, another element that demonstrates the use of differentiation is that at various stages, the company has acquired technology that enables it to innovate in its production processes [11]. For some details see Table 4 below.

\section{The strategy of focus}

Regarding the strategy based on product lines focus, CEMEX has various types of cement focused on meeting the needs of the different regions of the country. For example, it offers the Portland Cement Composite Impercem, which is focused to work under wet ambient. Also, it features the Portland Cement Resistant to Sulfates, which is used in the construction of canals, dams, drainage or similar environments [11]. In Table 5 it is specified each product and its area of focus. Then the geographic areas in which each product is distributed are described below (Table 5).

CEMEX Cement Monterrey, this brand is distributed in Coahuila, Durango, Zacatecas, SLP, Nuevo Leon and Tamaulipas. CEMEX Tolteca Cement, this brand is available in Nayarit, Colima, Jalisco, Michoacán, State of Mexico, Queretaro, Hidalgo, Mexico City, Puebla, Tlaxcala, Guerrero, Oaxaca, Morelos and Chiapas. CEMEX Cement Anahuac is positioned in Veracruz. CEMEX cement Gallo, distributed in Baja California and Baja California Sur. CEMEX Cement Gallo, available in the state of Sonora; CEMEX Cement Centenario, is sold only in Sinaloa. CEMEX Cement Maya is distributed in the states of Campeche, Quintana Roo and Yucatan [11].

\section{Conclusions}

In conclusion, from the result that throws the concentration index of Herfindahl - Hirshman (HHI), which was performed with the data of Total Gross Production, it can be said that the structure of the construction industry in Mexico tends to be oligopolistic. This proved by seeing that in this country, the production of materials such as cement, concrete and related products is carried out by six companies, among which is CEMEX, which has about $44 \%$ of market share.

Moreover, evidence obtained from the processing of the number of economic units registered in the DENUE [10] indicate that in the construction industry of Mexico there are three geographical areas of great interest, namely Mexico City, Nuevo Leon and Jalisco. The proportion of economic units of these three states together is equivalent to about $22 \%$ of the total industry. In the case of CEMEX, these states have served as strategic points to serve nearby markets, which have been a foundation for geographical expansion both within Mexico, as at company level.

The industry analysis that was conducted at the three aforementioned states, it is observed a repetitive pattern, which is

\begin{tabular}{|c|c|}
\hline Cemento CEMEX Monterrey & Cemento CEMEX Tolteca \\
\hline Cemento CEMEX Anahuac & Cemento CEMEX Gallo \\
\hline Cemento CEMEX Campana & Cemento CEMEX Centenario \\
\hline Cemento CEMEX Maya \\
\hline
\end{tabular}

Source: CEMEX [11].

Table 4:Brands distributed by CEMEZ México. 


\begin{tabular}{|l|l|l|}
\hline Product & Portland cement comprises & Composite Portland cement whit \\
\hline Focus Area & $\begin{array}{l}\text { Major performance and } \\
\text { endurance }\end{array}$ & $\begin{array}{l}\text { For use on ornamentals and } \\
\text { architectural works }\end{array}$ \\
\hline Product & $\begin{array}{l}\text { Portland cement compound } \\
\text { Impercem }\end{array}$ & $\begin{array}{l}\text { Portland cement composite } \\
\text { Extra }\end{array}$ \\
\hline Focus Area & For wet environments obrasen & Reduce cracking \\
\hline Product & $\begin{array}{l}\text { Portland cement sulphate } \\
\text { resistance }\end{array}$ & Ordinary Portland Cement \\
\hline Focus Area & $\begin{array}{l}\text { For the construction of canals, } \\
\text { dams, drainage and any related } \\
\text { construction }\end{array}$ & High strength and durability \\
\hline
\end{tabular}

Source: CEMEX [11].

Table 5: Product CEMEX and its focus area.

that the concentration of economic units is in enterprises employing less than 30 workers. This represents about $83 \%$ of such Units. The importance that this has for CEMEX is likely that in this sector a large proportion of its customers are found, so it is important to pay special attention to what happens there now. Based on the framework of the five forces, it seems that CEMEX currently has no potential rivals in the market for cement, concrete and its derivatives in Mexico. However, if CEMEX wants to keep the results it has achieved, should not neglect what they are doing their competitors, especially those with strong positions internationally, as in the case of Lafarge and Holcim Apasco.

As for the threat of new competitor's entries to the market of cement, concrete and its derivatives in Mexico, it is concluded that it is very low, because in the sector involved three of the most important companies worldwide [19]. This is generating the inability to compete against low cost of producing to gain scale of these firms, their experience, and the fact of facing high barriers to entry.

In the case of bargaining power of suppliers, it is concluded that only those that provide inputs directly related to the production process they are acquired at high levels, which does not happen with other suppliers. Regarding the bargaining power of buyers, it is concluded that it is low given the high number of economic units identified in the industry [20]. Speaking of threats of substitutes, the results indicate that in recent years has increased the interest in developing materials based on other inputs, and that they are of higher quality. However, currently they are not an issue for CEMEX and companies in the industry, although this fact does not mean or anything, that these actions are not to be taken into account.

Finally, it is clear that CEMEX been known to use the generic strategies proposed by Porter to develop some of the competitive advantages over its competitors. In that vein becomes possible to identify that the company has used the strategy of cost leadership during various stages of its productive life. On the other hand, evidence of the use of the differentiation strategy can also be found through the placement of various brands in different regions of Mexico, as well as how to serve customers. And finally, CEMEX focuses on adapting its products to the different needs of the regions where it places its brands.

\section{References}

1. Porter ME (1980) Competitive strategy: Techniques for analyzing industries and competitors. The Free Press.

2. Porter ME (1981) The contributions of industrial organization to strategic management. The Academy of Management Review 6: 609-620.

3. Bain JS (1968) Industrial organization: A Treatise. John Wiley, New York.

4. Bain JS (1972) Essays on price theory and industrial organization. Littre, Brown

5. Caves RE (1980) Industrial organization, corporate strategy and structure Journal of Economic Literature 18: 64-92.

6. Vargas Hernández JG, Guerra GE, Bojórquez GA, Bojórquez GF (2014) Strategic management in basic education institutions in Mexico. Universidad de Guadalajara.

7. Peng MW (2010) Estrategia global. CENGAGE Learning

8. North D (1990) Institutions, institutional change, and economic performance. Cambridge University Press.

9. INEGI (2015) Economic census.

10. DENUE (2014) National Statistics Directory of Economic Units. INEGI.

11. CEMEX (2015) Building a better future. Mexico.

12. Grupo Cementos de Chihuahua, SAB de CV (2015) Americas Business Insight in Latin.

13. CANACEM (2015) National cement chamber plants.

14. Holcim-Apasco (2015) Perfil Holcim Mexico

15. Cementos Moctezuma (2015) Infrastructure plants

16. CNN Expansion (2014) Elementia stays with $100 \%$ of Cementos Fortaleza.

17. Excelsior (2012) Mexican create substitute the traditional concrete. The MasaRoca is a building material to be marketed after proving high quality standards that exceed the traditional concrete.

18. La Republica LR (2014) Argos makes testing possible substitutes cement

19. Alto N (2013) Slim Valley and reconfigure the cement industry.

20. Financial EI (2014) CEMEX $17.6 \%$ increase in capacity in Mexico plant expansion. EMPRESAS. 